\title{
Is it necessary to reduce the radioiodine dose in patients with thyroid cancer and renal failure?
}

\author{
É necessário reduzir as atividades de radioiodo nas terapias \\ de pacientes com câncer de tireoide e disfunção renal?
}

José Willegaignon ${ }^{1,2}$, Verena Pinto Brito Ribeiro', Marcelo Sapienza ${ }^{1,2}$, Carla Ono ${ }^{1,2}$, Tomoco Watanabe ${ }^{1,2}$, Carlos Buchpiguel ${ }^{1,2}$

\section{SUMMARY}

The objective of this study were to obtain dosimetric data from a patient with thyroid cancer simultaneously undergoing peritoneal dialysis therapy, so as to determine the appropriate amount of ${ }^{131}$ l activity to be applied therapeutically. Percentages of radioiodine in the blood and the whole-body were evaluated, and radiation absorbed doses were calculated according to OLINDA/EXM software. Whole-body ${ }^{131}$ I effective half-time was 45.5 hours, being four times longer than for patients without any renal dysfunction. Bone-marrow absorbed dose was 0.074 $\mathrm{mGy} / \mathrm{MBq}$, with ablative procedure maintenance at $3.7 \mathrm{GBq}$, as the reported absorbed dose was insufficiently restrictive to change the usual amount of radioiodine activity administered for ablation. It was concluded that radioiodine therapeutic-dose adjustment, based on individual patient dosimetry, is an important way of controlling therapy. It also permits the safe and potential delivery of higher doses of radiation to tumors and undesirable tissues, with a minimum of malignant effects on healthy tissues. Arq Bras Endocrinol Metab. 2010;54(4):413-8

\section{SUMÁRIO}

O objetivo do presente estudo foi determinar a atividade de radioiodo a ser administrada na terapia de um paciente portador de câncer de tireoide e simultaneamente tratado com diálise peritoneal. Percentuais de radioiodo em sangue e corpo-total foram avaliados após a administração de uma atividade traçadora e a dosimetria foi calculada utilizando o software OLINDA/ EXM. A meia-vida efetiva do radioiodo em corpo-total foi de 45,5 horas, sendo quatro vezes maior que aquela observada em pacientes sem disfunção renal. A dose em medula óssea foi de 0,074 mGy/MBq, administrando-se uma atividade terapêutica de 3,7 GBq, uma vez que a estimativa de dose não foi suficientemente restritiva para mudar a atividade usual de radioiodo com função ablativa. Concluiu-se que a terapia individualizada de pacientes permite manter o equilíbrio entre o máximo de dose de radiação liberada em tumores ou tecidos indesejados

\author{
Correspondence to: \\ José Willegaignon \\ Centro de Medicina Nuclear, \\ Instituto de Radiologia \\ Hospital das Clínicas, FMUSP \\ Travessa da Rua Dr. Ovídio Pires de \\ Campos, s/n \\ 05403-010 - São Paulo, SP, Brazil \\ willegaignon@hotmail.com
}

Received on Sept/15/2009 Accepted on Jan/5/2010 com o mínimo de efeitos maléficos sobre tecidos sadios. Arq Bras Endocrinol Metab. 2010;54(4):413-8

$\mathrm{T}$ hyroid cancer is the most frequently occurring endocrinal tumor, although it represents less than $1 \%$ of all malignant tumors diagnosed worldwide (1). Patient management usually consists of thyroidectomy, either entire or nearly so, followed by radioiodine therapy in the case of differentiated thyroid cancer (papillary and follicular tumors).

Radioiodine therapy is applied in the removal of remanent thyroid tissue after gland surgery, and in the treatment of metastases, eventually suspected or detected by clinical diagnosis, accordingly clinically important, especially in reducing recurrence (2).

Around ninety percent of administered radioiodine activity is excreted mainly through the kidneys. Thus, patients with renal insufficiency may retain radioiodine activity over a long period, thereby leading to more intense internal exposure to radiation than that observed in normal ones (3). Reports on patients with renal dysfunction simultaneously undergoing radioiodine treatment are rare in literature (4), although less so as 
regards concurring hemodialysis. Consequently, there is little information available on radioiodine biokinetics as well as radiation dosimetry in patients with differentiated thyroid cancer (DTC) which are simultaneously undergoing continuous peritoneal dialysis (5-7). This lack of information gives rise to difficulties in determining the appropriate ${ }^{131} \mathrm{I}$ activities to be administered in this specific case. With this in mind, the expressed aim was to provide an alternative for defining the ideal dose in patient therapy, based on individually acquired radiometric data as well as to discuss the importance of this individualized approach in patients with renal insufficiency and in need of radioiodine therapy.

\section{CASE REPORT}

A 49-year-old female patient was diagnosed with DTC, a multicentric papillary microcarcinoma, with a follicular variant in both lobes. The largest tumor measuring $0.6 \mathrm{~cm}$ at the widest point and without cervical lymph node involvement (TlaNoMo). The patient was admitted for additional treatment with radioiodine therapy, in order to remove remanent thyroid tissue. Furthermore, and due to renal insufficiency, she was also submitted to once-daily and continuous peritoneal dialysis therapy while awaiting renal transplant. Identified as a rare case, and with the lack of information on radioiodine therapy under similar circumstances, she was submitted to a maximum-safe-dose procedure. The intention was to estimate the absolutely safest administrable activity, without the risk of severe medullar depression. This was based on the biokinetics of radioiodine excretion and retention, and on dose estimates for internal organs, especially the bone-marrow, by unit of administered activity. In order to thus proceed and write this report a signed informed consent was obtained from the patient.

Although it is questionable whether radioiodine therapy should be resorted to in low-risk or very lowrisk thyroid cancer patients, this particular one was treated on physician's recommendation. Furthermore, our lack of experience with this kind of subject led us to carry out conservative and well-established procedures without the use of rhTSH in this particular case.

After prior preparation for a logistic period of 35 days, by means of an iodine-poor diet and the suppression of hormonal reposition (thyroxine), TSH level reached $455 \mu \mathrm{U} / \mathrm{mL}$, thyroglobulin $6.0 \mathrm{ng} / \mathrm{mL}$ and anti-thyroglobulin negative. At this point, $74 \mathrm{MBq}(2$
$\mathrm{mCi}$ ) of ${ }^{131}$ I activity was administered orally in order to study internal radiotracer biokinetics. Absorbable doses of radiation by internal organs (Table 1 ) were furnished by OLINDA/EXM (8) software using a specific residence time of radioiodine in the patient's whole-body, corrected according to the patient's weight $(113 \mathrm{~kg})$ and estimated bone-marrow mass $(2.4 \mathrm{~kg})$, and calculated by assuming its variation against patient weight, as indicated by other authors (9).

Table 1. Estimated radiation absorbed dose to certain internal organs per unit of administered radioiodine activity

\begin{tabular}{|c|c|c|c|}
\hline Internal organ & $\begin{array}{c}\text { Absorbed } \\
\text { radiation } \\
\text { dose } \\
(\mathrm{mGy} / \mathrm{MBq})^{\mathrm{b}}\end{array}$ & Internal organ & $\begin{array}{c}\text { Absorbed } \\
\text { radiation } \\
\text { dose } \\
\text { (mGy/MBq) }\end{array}$ \\
\hline Brain & 0.113 & Ovaries & 0.148 \\
\hline Heart wall & 0.141 & Uterus & 0.147 \\
\hline Liver & 0.137 & Stomach wall & 0.140 \\
\hline Lungs & 0.128 & Pancreas & 0.150 \\
\hline Red marrow & 0.074 & Spleen & 0.137 \\
\hline Thyroid remainde & 78.700 & Small intestine & 0.137 \\
\hline Whole-body & 0.096 & Breasts & 0.105 \\
\hline
\end{tabular}

assuming $0.3 \mathrm{~g}$ of weight, and considering a radioiodine uptake of $1 \%$ of administered activity per gram of thyroid tissue; ${ }^{b} 1 \mathrm{mGy} / \mathrm{MBq}=37 \mathrm{mGy} / \mathrm{mCi}$.

The percentage of radioiodine in the blood and entire-body were calculated at 2, 4, 24, 48, 72 and 96 hours post-activity administration. Samples of dialyzed liquid were also analyzed so as to obtain the percentage of radioiodine activity excreted thereby. Activities in the blood and dialyzed liquid samples $(2 \mathrm{~mL})$ were estimated by using a ${ }^{131}$ I standard source of like volume, and a radiation detector signal (CPM, Counts Per Minute) provided by a well-counter (Captus 600 Well Counter System, Capintec Inc.). Before using the well-counter, the radiation detector was performance-tested by using a ${ }^{137} \mathrm{Cs}$ standard source of $500 \mathrm{nCi}$ (Lot \# 693-563/01-Jun-00). The maximum deviation between activities, as estimated by the detector, and the theoretical activity of the source, was $7.0 \%$. Each organic sample from the patient was measured five times, the time of measurement lasting two minutes. Standard deviation in all measurements was about $1.5 \%$.

Radioiodine uptake in the thyroid bed was assessed using a Captus 600 (Thyroid Uptake System, SN: 600269, Capintec Inc.). The patient herself was used as standard source for evaluating the remaining activity in her body, as a function of time versus post-activity 
administration. Slight renal activity with residual urine was observed in the patient. The activity level excreted thereby was not measured.

Whole-body scans were carried out at 4, 24, 48, 72 and 96 hours post-activity administration by using a gamma-camera (Model ECAM Gantry Dual Head Extended, SN: 7086, SIEMENS Medical System - USA). The pattern of radioiodine reduction throughout the whole-body and in the blood as a function of time and given the radioiodine effective half-time in both compartments can be seen in figure 1. Figure 2, shows the percentages of accumulated activity extracted from the patient's body as a function of elapsed time versus postactivity administration. Certain characteristics of each dialysis procedure undertaken until the fourth day postactivity administration are presented in table 2 . Anterior and posterior images of the whole-body are shown in figure 3 , together with some of the drawn ROIs used for complementary dosimetric studies.

On considering the radiation dose delivered to bone-marrow per unit of administered activity as 0.074 $\mathrm{mGy} / \mathrm{MBq}(2.738 \mathrm{mGy} / \mathrm{mCi})$, as indicated by OLINDA/EXM computational software, and based on information from Benua (10) to the effect that $2 \mathrm{~Gy}$ in bone-marrow is a safe dose, the absolutely safest activity to be applied in patient therapy would be 26.8 $\mathrm{GBq}(730 \mathrm{mCi})$. This was reduced to $3.7 \mathrm{GBq}(100$ $\mathrm{mCi}$ ) for ablation, since the estimated absorbed dose of radiation to bone marrow was insufficiently restrictive to change the usual amount of radioiodine activity specifically administered.

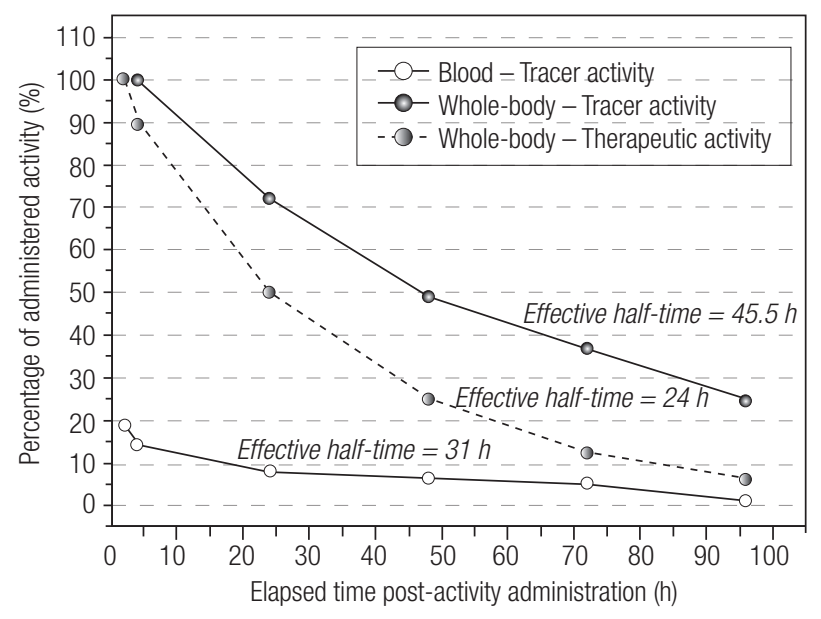

Figure 1. Percentage of administered activity in whole-body and blood as a function of elapsed time post-activity administration.

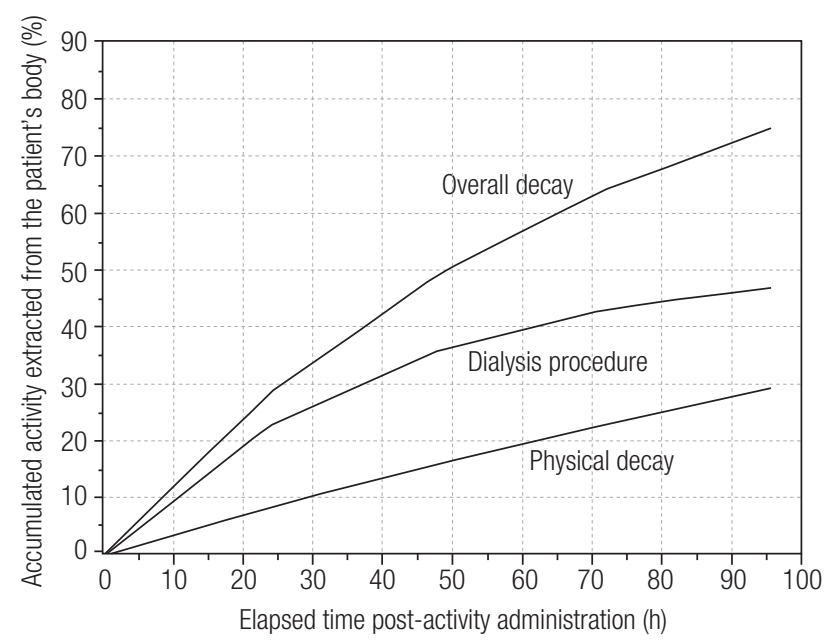

Figure 2. Percentage of accumulated activity extracted from the patient's body as a function of elapsed time post-activity administration.

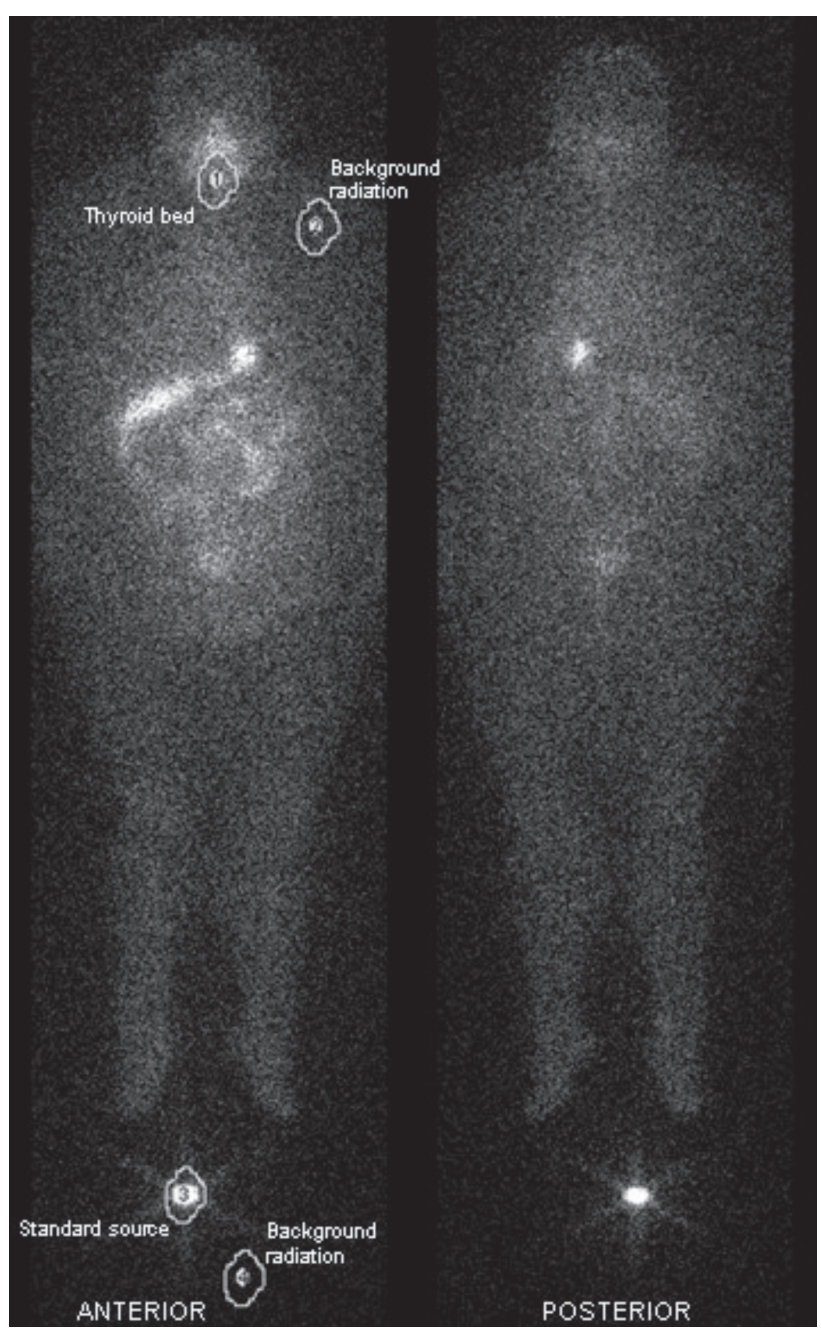

Figure 3. Whole-body scan with respective ROIs drawn for complementary dosimetric studies. 
Table 2. Some characteristics of each dialytic procedure performed until the fourth day post-tracer-activity administration

\begin{tabular}{lcccc}
\hline Day & $\begin{array}{c}\text { Dialysis } \\
\text { volume } \\
\mathbf{( m L )}\end{array}$ & $\begin{array}{c}\text { Activity } \\
\text { concentration } \\
\mathbf{( k B q} / \mathbf{m L})\end{array}$ & $\begin{array}{c}\text { Overall } \\
\text { Activity } \\
\mathbf{( M B q})^{\mathbf{a}}\end{array}$ & $\begin{array}{c}\text { Percentage of } \\
\text { administered } \\
\text { activity }\end{array}$ \\
\hline First & 13,492 & $0.720 \pm 0.011$ & $9.77 \pm 0.15$ & $13.20 \pm 0.20$ \\
Second & 13,510 & $1.07 \pm 0.016$ & $14.43 \pm 0.22$ & $19.50 \pm 0.29$ \\
Thirth & 13,452 & $0.420 \pm 0.006$ & $5.70 \pm 0.09$ & $7.70 \pm 0.12$ \\
Fourth & 13,389 & $0.270 \pm 0.004$ & $3.66 \pm 0.05$ & $4.90 \pm 0.07$ \\
\hline
\end{tabular}

${ }^{a} 1 \mathrm{MBq}=0.027 \mathrm{mCi}$.

\section{DISCUSSION}

Prolonged ${ }^{131} \mathrm{I}$ retention inside a patient's body is directly associated to the more probable appearance and severity of side-effects, as, for instance, sialoadenitis, xerostomia and gastritis, besides bone-marrow depression. This is due to the absorbed doses of radiation received by exposed internal organs during radioiodine therapy. Additional exposure is even liable to increase citogenetic alterations in blood constituents.

Apart from the excessive exposure to radiation undergone by the patients themselves, the delay in eliminating radioiodine may expose relatives, medical staff and others with added intensity. So unquestionably, there is still the need for further attention whenever radiopharmaceutical activities are being administered to patients with renal dysfunction.

The study of radioiodine biokinetics in the present case, led the way to defining a radioiodine-effective half-time of 45.5 hours (Figure 1) for the patient's whole-body, with residence time being estimated at 53.52 hours. These values are approximately 4 times greater than those estimated for patients with normal renal functions, where the values are 11.4 hours and 16.4 hours (11), respectively.

The dialysis process employed over the first four days post-tracer-activity administration led to the removal of $45 \%$ of all administered activity, a clearance rate of $0.5 \%$ per hour, with a mean concentration of $0.62 \mathrm{kBq}(0.02 \mu \mathrm{Ci})$ per $\mathrm{mL}$ dialyzed (Table 2 and Figure 2). Radioiodine uptake by the thyroid bed was $0.3 \%$ of total administered activity, as indicated through ROI methodology and direct measurement by using a specific thyroid uptake detector (Figure 3).

Apart from the specific removal rate observed in this particular patient, several studies have indicated that the percentage of radioiodine removed in one single session of dialysis varies from patient to patient, the results being strongly dependant on the dialytic methodology resorted to. In a case of 6 hourly-successive dialysis, Wang and cols. (4) reported the total excretion of $60 \%$ of administered activity at each dialytic session, and a retention index of $6.4 \%$ and $2.6 \%$ of total administered activity at 18 hours and 24 hours post-activity administration, respectively. For Toubert and cols. (7), daily clearance was $5.3 \%$ to $8.6 \%$ of the total administered activity over the first three days post-activity administration. Kaptein and cols. (6) presented similar results, with $26.9 \%$ mean elimination at each session of dialysis, 24 hours after activity administration. Holst and cols. (3) showed that the percentage of ${ }^{131} \mathrm{I}$ in a session of hemodialysis ranged from a minimum of $38 \%$ up to a maximum of $80 \%$ of all activity existing inside the patient's body before initiating the procedure.

Moreover, Holst and cols. (3) confirmed the variability of radioiodine clearance at each session. This varied according to the type of dialysis employed (hemodialysis or peritoneal dialysis), and depended on the internal characteristics of each patient, the peritoneal membrane of each, the duration of each dialysis, the elapsed time between activity administration and the first dialysis, the elapsed time between two successive dialyses, and glucose concentration, besides other factors.

Use has been made of several different methodologies in order to determine the optimal amount of radioiodine activity to be administered to patients with impaired renal function, with a view to eradicating remanent thyroid tissue after clinical surgery. Some authors have given activities based on delivering 300 Gy to this tissue (7), whereas others have chosen to reduce these to about $25 \%$ in the case of administration to patients without renal dysfunction $(6,7)$. In a comparative study by Holst and cols. (3), it was shown that certain authors applied activities as low as $0.92 \mathrm{GBq}(25 \mathrm{mCi})$ and as high as $9.2 \mathrm{GBq}(250 \mathrm{mCi})$ in the treatment of patients with impaired renal function. They placed in evidence the lack of consensus on the level of radioiodine activity necessary for therapy, and at the same time, safe for patients with thyroid cancer and simultaneously undergoing hemodialysis or peritoneal dialysis. Yet, it is noteworthy that whether applying low or high activity, many patients required further treatment with radioiodine for a persistent disease. This was probably due to the dose of absorbed radiation achieved being insufficient to meet the patient's needs, either for ablative or therapeutic purposes. One example of this can be extracted from the work of Wang and cols. (4), where 
they administered an activity of $5.5 \mathrm{GBq}(150 \mathrm{mCi})$ to a patient after observing that an activity of $1.1 \mathrm{GBq}$ $(30 \mathrm{mCi})$ produced an insufficiently absorbed dose for treatment.

With the aim of maintaining the absorbed dose in the bone-marrow of patients with renal dysfunction and simultaneously undergoing peritoneal dialysis, equal to that received by patients with preserved renal functions, Kaptein and cols. (6) reduced the usual activity from $5.5 \mathrm{GBq}(150 \mathrm{mCi})$ to $0.98 \mathrm{GBq}(26.6 \mathrm{mCi})$ and $1.1 \mathrm{GBq}(29.9 \mathrm{mCi})$ in the therapy of two patients thus being treated. Moreover, on considering an estimation of $300 \mathrm{~Gy}$ in remanent thyroid tissue which was ultrasonographically evaluated at $0.6 \mathrm{~g}$, Toubert and cols. (7) indicated an activity of $0.81 \mathrm{GBq}(22 \mathrm{mCi})$ for a patient undergoing peritoneal dialysis, instead of the usual activity of $3.7 \mathrm{GBq}(100 \mathrm{mCi})$ for ablation.

The definition of radioiodine activities based on an estimation of $300 \mathrm{~Gy}$ in remanent thyroid tissue is still quite questionable. This is mainly due to the uncertainties and limitations of each method when estimating the amount of tissue involved. Tissue mass estimated by ultrasonography, scintigraphy or radioiodine uptake in the cervical area may incur inaccuracy and innate difficulties in determining volumetric and mass dimensions in structures with a highly variable morphology. This occurs through using imprecise measurement methodologies as well as the extreme variability in radioiodine uptake brought about by the functional behavior of the remaining cells in the thyroid bed after surgery (12-15).

The above-mentioned points exemplify the different ways by which specialists adapt the administration of radioiodine activity to patients with various forms of thyroid cancer and impaired renal functions. However, and apart from this, the main point under consideration is to identify the plausible amount of radioiodine activity to be administered, so as to reach the maximum probability of eradicating remanent thyroid tissue or metastases, with a minimum of side effects from radioiodine therapy itself. It seems that the answer to this question doubtlessly points to determining activities based on biokinetics and individual dosimetry. A further consideration is that side effects are produced by the absorbed radiation dose, which is, in turn, directly proportional to radioiodine uptake and its time of retention inside the patient's body.

When considering that patients with thyroid cancer who are at the same time undergoing peritoneal dialysis, are rare cases, it is statistically difficult to analyze the efficiency of radioiodine therapy therein. Nevertheless, it is possible to have some idea when observing therapeutic efficiency in patients without renal dysfunction. In literature, activities as low as $1.8 \mathrm{GBq}(50 \mathrm{mCi})$ or 1.1 $\mathrm{GBq}(30 \mathrm{mCi})$ have failed in therapy in about $40 \%$ to $50 \%$ of the cases (16-18), when prior dosimetric studies were unavailable. Thus, the administration of similar activities to patients should be avoided, except in specific and documented cases, or when dosimetric studies have preceded therapy.

In the present specific case, the absorbed dose received by the whole-body was estimated at $0.096 \mathrm{mGy} /$ $\mathrm{MBq}(3.55 \mathrm{mGy} / \mathrm{mCi})$, and by the bone-marrow $0.074 \mathrm{mGy} / \mathrm{MBq}(2.738 \mathrm{mGy} / \mathrm{mCi})$. These values were 2.2 and 1.9 times higher than those estimated for patients without renal dysfunction, estimated at 0.044 $\mathrm{mGy} / \mathrm{MBq}(1.628 \mathrm{mGy} / \mathrm{mCi})$ for the whole-body and $0.038 \mathrm{mGy} / \mathrm{MBq}(1.406 \mathrm{mGy} / \mathrm{mCi})$ for bonemarrow, respectively. Based on the dose of absorbed radiation delivered to the bone-marrow per administered activity, and 2 Gy (10) as being a safe limit for avoiding significant medullary depression, the absolutely safest activity to be applied in the therapy under consideration would be $26.8 \mathrm{GBq}(730 \mathrm{mCi})$.

Furthermore, an ablative procedure with $3.7 \mathrm{GBq}$ $(100 \mathrm{mCi})$ was indicated, on considering the clinical stage of the disease, the safest applicable activity and the possibility of obtaining low efficacy when applying small doses. In addition, the reported absorbed doses were not restrictive enough to reduce the usual amount of radioiodine activity administered to patients for ablation.

A limitating factor in the present work was not having previously compared biokinetic and dosimetric data obtained from tracer-activity administration with those from therapeutic procedures. In the latter, only radioiodine effective half-time in the patient's whole-body was estimated. Even so, this was done by using a different way of measuring (exposure rates at $1.0 \mathrm{~m}$ from the patient's body using a Geiger-Müller detector). Thus, all absorbed radiation doses were assessed only on considering radiometric data from tracer studies.

On considering the rare occurrence of thyroid cancer in patients with renal dysfunction and undergoing peritoneal dialysis, with scarce mention in current literature, it is our belief that there will be some delay in arriving at a consensus on the ideal management of this type of patient. This situation will persist, at least until an appreciable amount of radiometric data has been accumulated and fresh studies undertaken, thereby gi- 
ving rise to novel considerations, and the availability of improved alternatives for treatment. Thus, the fundamental intention hereby is not to add a novel therapeutic model for application in like situations, but to aggregate radiometric data from a real-life case. This would validate the use of individual dosimetry, thereby leading to a more individualized therapy. This, in our opinion, is the future path for any type of treatment based on radiopharmaceutical therapy.

In conclusion, the adjustment of radioiodine therapeutic doses based on individual patient dosimetry is an important way of keeping therapy under control. This would permit the safe and potential delivery of higher doses of radiation to tumors and undesirable tissues, with minimal malignant side-effects. This is the reason for concentrated attention in the treatment of patients suffering from renal failure.

Disclosure: no potential conflict of interest relevant to this article was reported.

\section{REFERENCES}

1. Golbert L, Wajner SM, Rocha AP, Maia AL, Gross JL. Carcinoma diferenciado de tireóide: avaliação inicial e acompanhamento. Arq Bras Endocrinol Metab. 2005;49:701-10.

2. Mazzaferri EL, Kloos RT. Clinical review 128: current approaches to primary therapy for papillary and follicular thyroid cancer. J Clin Endocrinol Metab. 2000;86:1447-63.

3. Holst JP, Burman KD, Atkins F, Umans JG, Jonklaas J. Radioiodine therapy for thyroid cancer and hyperthyroidism in patients with end-stage renal disease on hemodialysis. Thyroid. 2005;15:1321-31.

4. Wang TH, Lee $\mathrm{CH}$, Tseng LM, Liu RH. The management of welldifferentiated thyroid cancer with end-stage renal disease. Endocrine. 2003;21:227-31.

5. Magné N, Magné J, Bracco J, Bussière F. Disposition of radioiodine ${ }^{131} \mid$ therapy for thyroid carcinoma in a patient with severely impaired renal function on chronic dialysis: a case report. Jpn J Clin Oncol. 2002;32:202-5.

6. Kaptein EM, Levenson H, Siegel ME, Gadallah M, Akmal M. Radioiodine dosimetry in patients with end-stage renal disease receiving continuous ambulatory peritoneal dialysis therapy. J Clin Endocrinol Metab. 2000;85:3058-64.

7. Toubert ME, Michel C, Metivier F, Peker MC, Rain JD. lodine-131 ablation therapy for a patient receiving peritoneal dialysis. Clin Nuclear Med. 2001;26:302-5.

8. Stabin MG, Sparks RB, Crowe E. OLINDA/EXM: the second-generation personal computer software for internal dose assessment in nuclear medicine. J Nucl Med. 2005;46:1023-7.

9. Wessels BW, Bolch WE, Bouchet LG, Breitz HB, DeNardo GL, Meredith RF, et al. Bone marrow dosimetry using blood-based models for radiolabeled antibody therapy: a multiinstitutional comparison. J Nucl Med. 2004;45:1725-33.

10. Benua R, Cicale NR, Sonenberg M, Rawson RW. The relation of radioiodine dosimetry to results and complications in the treatment of metastatic thyroid cancer. Am J Roentgenol Radium Ther Nucl Med. 1962;87:171-82.

11. Willegaignon J, Malvestiti LF, Guimarães MI, Sapienza MT, Endo IS, Neto GC, et al. ${ }^{131}$ effective half-life $\left(T_{\text {eff }}\right)$ for patients with thyroid cancer. Health Phys. 2006;91:119-22.

12. Pant GS. Dosimetric and radiation safety consideration in radioiodine therapy. Ind J Nucl Med. 2005;20:1-3.

13. Zaidi H. Comparative methods for quantifying thyroid volume using planar imaging and SPECT. J Nucl Med. 1996;37:1421-26.

14. Kiratli PO, Gedik GK. Problems and pitfalls in thyroid uptake measurements with iodine-131. Hell J Nucl Med. 2008;11:187-8.

15. Alevizaki C, Molfetas M, Samartzis A, Vlassopoulou B, Vassilopoulos $C$, Rondogianni P, et al. lodine 131 treatment for differentiated thyroid carcinoma in patients with end stage renal failure: dosimetric, radiation safety, and practical considerations. Hormones. 2006;5:276-87.

16. Bal CS, Kumar A, Pant GS. Radioiodine dose for remnant ablation in differentiated thyroid carcinoma: a randomized clinical trial in 509 patients. J Clin Endocrinol Metab. 2004;89:1666-73.

17. Ramirez M, Gonzalez JPO. Treatment of differentiated thyroid cancer with low dose of I-131. World J Nucl Med. 2004;3(Suppl 1):S44.

18. Sirisalipoch S, Buachum V, Pasawang P, Tepmongkol S. Prospective randomised trial for the evaluation of the efficacy of low vs. high dose I-131 for post operative remnant ablation in differentiated thyroid cancer. World J Nucl Med. 2004;3(Suppl 1):S46. 